\title{
Guerra, domínio e soberania: experiências coloniais e império no Atlântico Sul, década de 1570
}

\author{
por \\ Rodrigo Faustinoni Bonciani \\ Universidade Federal da Integração Latino-Americana (UNILA) \\ rodrigobonciani@gmail.com
}

Por meio da análise de documentos e da historiografia, o artigo identifica a constituição de um campo unificado de experiências de colonização no Atlântico Sul, durante a década de 1570. A caracterização da autoridade régia sobre os espaços coloniais se dava, por um lado, pela instituição de um aparato político-administrativo, por outro, pela intervenção nas relações de domínio senhorial estabelecidas sobre os indígenas e africanos. Esse último era o ponto de compromisso e dissensão, que definia o equilíbrio instável entre os poderes coloniais $e$ as autoridades europeias, por meio de um sistema de exploração compósito, caracterizado pela complementaridade entre diferentes estatutos e formas de dominação.

PalaVRas-chave: guerra; domínio; soberania; império; Atlântico Sul.

Entre os séculos XV e XVI foi estabelecido um campo unificado de experiências de dominação e soberania que, para além das particularidades de Castela e Portugal, possuía uma perspectiva ibérica e global. A dimensão sul-atlântica dessa política imperial delineou-se entre as décadas de 1570 e 1590. A «conquista de Angola», que viabilizou a ampliação do tráfico de escravos, e a do último reduto inca, associadas a um novo momento da política indigenista e de governo nas Américas, foram os eventos desencadeadores dessa construção. A legitimação do domínio ibérico sobre as Américas e as modalidades de sujeição dos ameríndios se definiram em consonância com a política em relação aos reis e chefes da África subsaariana e o desenvolvimento do tráfico negreiro. A partir da década de 1570, a ideia de complementaridade 
entre a África e as Américas se transformou em uma política consciente por parte das Coroas ibéricas.

Na América portuguesa, o governo de Mem de Sá (1557-1572) deu as bases para a consolidação da colonização porque definiu as formas de incorporação dos ameríndios à sociedade colonial, favorecendo diferentes forças sociais. Essa política se desenvolveu em perspectiva dialógica com a experiência castelhana, particularmente no Peru, e atenta às notícias e «peças» que vinham da Guiné, São Tomé, Congo e Angola. No fim do mandato de Mem de Sá, a Coroa portuguesa, pela primeira vez, tomou medidas coordenadas em relação ao tráfico de escravos africanos e à legislação indigenista. No ano de 1570, a Mesa de Consciência e Ordens definiu, simultaneamente, os termos da primeira lei para os índios do Brasil e os da carta de doação e conquista de Angola. Antes, portanto, do estabelecimento do governo-geral em Angola ou dos conflitos sul-atlânticos entre a monarquia hispânica e os Países Baixos, a Coroa portuguesa revelava sua política imperial que vinculou as duas margens do Mar Oceano ${ }^{1}$.

Nas Índias Ocidentais, desde o princípio da colonização, a importação de africanos era vista como uma alternativa para complementar os sistemas de exploração e dominação dos ameríndios. A partir de 1542 se consolidou a postura da Coroa castelhana contra as conquistas armadas e a escravização indiscriminada dos índios, mas o ambiente americano ainda dependia da ação privada dos conquistadores. A polêmica entre Bartolomé de las Casas e Juan Ginés de Sepúlveda pôs em cena as posturas antagônicas que justificavam o domínio castelhano sobre a América. Em posição diametralmente oposta à perspectiva das Leyes Nuevas, Felipe II aprovou, em 1556, a venda de encomiendas perpétuas no Peru.

Um novo contexto foi vislumbrado entre o fim da década de 1560 e início da de 70. Primeiro pelo Tratado de Acobamba e, em seguida, pela determinação do vice-rei Francisco de Toledo de conquistar Vilcabamba e reformar o sistema de trabalho e tributação das sociedades indígenas ${ }^{2}$. Justificada a conquista espanhola de Tawantinsuyo e a forma de exploração das riquezas peruanas, a Coroa passou a definir as novas bases de legitimação de seu poder sobre a América. O jurista Juan de Ovando realizou uma detalhada inspeção no Conselho de Índias e iniciou uma compilação das «leis indianas», que resultaram na redação das Ordenanzas de descubrimiento, nueva población y pacificación, em 1573. O novo contexto americano, definido pelo estabelecimento de espaços de domínio europeu, pela eliminação da autoridade inca e pela intensificação da atividade econômica, permitia falar em direito adquirido,

\footnotetext{
1 Desta forma, antecipamos os marcos analíticos propostos por Alencastro, 2000: 327-340.

2 Julien, 2007: 243-272.
} 
em domínio de fato. Em 1574, Felipe II avaliava a possibilidade de colocar o tráfico de escravos sob monopólio régio para vendê-los aos colonos.

A definição desses novos marcos da colonização sul-atlântica foi também o resultado das transformações e experiências nas relações de poder e dominação no contexto europeu. A bancarrota financeira de 1575 aumentou a dependência da Coroa castelhana pelas minas americanas. A morte de Isabel de Valois, terceira mulher de Felipe II, precipitou o conflito religioso europeu, que desencadeou as guerras de independência nos Países Baixos. Somam-se a isso as derrotas perante o Império Otomano, depois da batalha de Lepanto e a revolta dos mouros em Granada ${ }^{3}$. Todos esses eventos deixaram a política Habsburgo em situação extremamente frágil na Europa. A perspectiva de um império ultramarino atlântico, e sua conexão asiática, favoreceu a ideia de união das Coroas ibéricas, estimulada pela presença de Catarina de Áustria em Portugal, e realizava uma alternativa política idealizada há pelo menos cem $\operatorname{anos}^{4}$. A década de 1570 foi um momento chave desse processo.

\section{Sujeição, descimento E gOVerno na América PORTUGUesa}

De acordo com a política de diversificação dos agentes responsáveis pelo domínio sobre os indígenas, as Coroas ibéricas favoreceram, entre as décadas de 1550 e 1580, a mediação dos governadores-gerais e vice-reis. O favorecimento dessa mediação visava destacar o lugar da autoridade régia na ordenação das sociedades coloniais, sendo o domínio sobre as populações indígenas o elemento de tensão e de realização desse poder. Destaco neste artigo, a atuação de Mem de Sá no governo do Brasil (1557-1572) e, para o Peru, a do vice-rei D. Francisco de Toledo (1569-1581).

A carta de nomeação de Mem de Sá diz expressamente que as doações de capitanias não embargavam os poderes a ele delegados, que possuía uma jurisdição superior e tinha o direito de suspender os capitães-donatários ${ }^{5}$. Seu governo deu as novas bases da colonização portuguesa na América e, além de consolidar a aliança entre a Coroa e a Companhia de Jesus, a aprovação geral de seu governo indica o favorecimento de outros grupos sociais. Um

${ }^{3}$ Catherine Julien demonstra as aproximações entre a política de guerra e domínio travada pelos espanhóis contra os muçulmanos em Granada e os indígenas do Peru. Ibidem: 251-253.

${ }^{4}$ Bouza, 1995, vol. 3: 1.458-1.459.

${ }^{5}$ Nomeado em 23 de julho de 1556, por três anos e com os mesmos vencimentos e poderes de seu predecessor. "Carta Régia pela qual Sua Majestade fez mercê a Mem de Sá de Governador-geral das Capitanias do Brasil, 23 de julho de 1556", Anais da Biblioteca Nacional do Rio de Janeiro (ABNRJ), (1906): 219-221. 
documento fundamental para avaliar a política de Mem de Sá é a sua carta de serviços ${ }^{6}$. Os diferentes itens que compõem esse documento revelam a importância estratégica do Brasil para as expedições que rumavam para o Oriente, a relevância da atuação do governador nas contendas locais, no incremento da fazenda régia e na construção dos marcos que representavam a ordenação do espaço segundo a lógica colonial - os templos religiosos, a fortaleza e a casa dos governadores. Mas o aspecto mais importante de seus serviços refere-se ao domínio sobre os indígenas no Brasil.

As alianças estratégicas e as guerras foram o ponto de partida de sua ação ${ }^{7}$ e, a partir delas, foram estabelecidas as seguintes formas de sujeição:

1) Escravização dos prisioneiros de guerra ${ }^{8}$ ou por resgate 9

2) Administração de aldeamentos ${ }^{10}$ por $\operatorname{colonos}^{11}$.

3) Administração de aldeamentos a cargo dos jesuítas ${ }^{12}$.

6 "Instrumentos dos serviços de Mem de Sá, 7 de setembro de 1570", ibidem: 129-218. Os instrumentos ou cartas de serviço eram documentos elaborados pelos governadores, nos quais eram pontuados os feitos prestados à Coroa durante o mandato, em seguida, eram chamadas pessoas de destaque na vida social para discorrer sobre cada um dos itens indicados pelo governador; um escrivão registrava o depoimento desses «homens bons». Foi o primeiro documento do gênero no Brasil e se às práticas políticas que assemelha estavam sendo implementadas nas Índias Ocidentais.

7 Vainfas, 1995: 47-48.

${ }^{8}$ Destaca-se a guerra justa contra os caetés. Em junho de 1556, o bispo Sardinha e outros companheiros foram devorados em um ritual de antropofagia que justificou um decreto de guerra justa e escravização, feito pelo governador, por volta de 1562, e aceito pelos jesuítas. Thomas, 1981: 78-80.

${ }^{9}$ Partindo das experiências de escravização na Guiné, o resgate referia-se às formas indiretas de aquisição de escravos, provenientes de guerras intestinas, da punição de crimes, da venda de si ou de um filho por necessidade, ou do comércio interno.

${ }^{10}$ Utilizo a palavra «aldeia» para designar a povoação indígena organizada segundo as referências sociais e culturais dessas populações, enquanto que o termo «aldeamento» define o povoamento fixado compulsoriamente segundo as autoridades coloniais.

${ }^{11}$ Há pouca informação documental sobre os aldeamentos sob administração dos colonos. Em São Paulo, por exemplo, os deputados da Câmara elegeram um capitão dos índios em 1553, nas palavras de Georg Thomas: «A imposição do capitão assegurou, pois, à população de São Paulo, um direito fundamental de intervenção ativa no cuidado dos índios, antes que os jesuítas tivessem podido construir uma administração nas aldeias de acordo com o modelo da Bahia». Thomas, 1981: 90.

${ }^{12}$ No caso dos índios do chefe Boca Torta, a guerra foi justificada por causa de «canibalismo», as pazes foram concedidas pela conversão ao cristianismo e pelo ajuntamento das aldeias. Entregues à tutela jesuítica, eles se transformaram no principal apoio militar do governador na Bahia. Foi no Recôncavo Baiano que se estabeleceram os primeiros aldeamentos sob administração jesuíta, havia dez missões entre a Bahia e Camamu. 
4) Administração de aldeamentos por capitães leigos (diretamente vinculados ao governador e à Coroa) ${ }^{13}$.

5) Administração de aldeamentos por chefes indígenas ${ }^{14}$.

6) Diferenciação entre a administração temporal e a espiritual ${ }^{15}$.

A prontidão com que Mem de Sá atuou indica um mapeamento prévio das relações com diferentes etnias e grupos indígenas e um planejamento das guerras. O governador atuou em sete capitanias (Bahia, Itaparica, Ilhéus, Porto Seguro, Espírito Santo, Rio de Janeiro e São Vicente) e atendeu aos interesses de diferentes forças sociais (Coroa, jesuítas, lideranças indígenas, moradores, capitães, bem como para seu próprio benefício por meio de suas relações familiares). A atuação de Mem de Sá é exemplar porque mostra a capacidade de favorecer diferentes grupos presentes no processo de colonização, ao mesmo tempo em que revela sua autonomia, que o beneficiava pessoalmente e podia contradizer algum aspecto da política régia e reafirmar algumas tensões sociais presentes nos espaços coloniais.

Paralelamente ao incentivo da política conduzida por Mem de Sá em relação aos indígenas, a Coroa estimulou a importação de escravos africanos, particularmente do Congo e por via de São Tomé. Deu, por exemplo, estímulos fiscais para os senhores de engenho, reconhecendo que o estabelecimento de uma política indigenista dependia da ampliação da escravidão negra no Brasil ${ }^{16}$. Essa consciência estava presente entre os diferentes agentes sociais e pode ser exemplificada com a seguinte passagem de uma carta do padre Manuel da Nóbrega:

De Sant Vicente escrevi, conformando-me com o Padre Luís da Grã, que nos parecia não se haver de aceitar d'El-Rey terras nem escravos para granjearia. Agora, conformando-me com o que de lá [São Vicente] escrevem e com o parecer dos Padres de aqui [Bahia], digo que se aceite tudo até palhas; e digo que se S. A. nos

13 Destaca-se a criação do cargo de mamposteiro, um oficial civil, designado para cada capitania, com a função de guardar a legislação indigenista. Schwartz, 2011: 50-52.

${ }^{14}$ É o caso dos índios «tapuias» de Paraguaçu, chefiados por Tarajó. O depoente Vicente Dias confirma o pagamento de tributos à Coroa. "Instrumentos dos serviços de Mem de Sá", ABNRJ (1906): 192.

${ }^{15}$ Segundo Gabriel Soares de Sousa, Mem de Sá havia determinado a separação entre a administração espiritual, entregue aos jesuítas, e a administração temporal, sob responsabilidade de um meirinho (oficial de justiça de jurisdição inferior, aparecem também os termos «protetor», «capitão», «juiz» e «alcaide» para designar esse cargo). Os meirinhos podiam ser portugueses ou indígenas. "Capítulos que Gabriel Soares de Sousa deu em Madrid ao Sr. D. Cristovam de Moura, 1592", ABNRJ (1942): 341-381.

${ }^{16}$ Alvará sobre se poderem trazer escravos de São Tomé, 29 de março de 1559, Documentos para a história do açúcar, 1954, vol. 1: 147-149. 
quisesse mandar uma boa dada de terras, onde ainda não for dado, com alguns escravos de Guiné (...). Escravos da terra não nos parece bem tê-los por alguns inconvenientes. Destes escravos de Guiné manda ele trazer muitos à terra ${ }^{17}$.

A necessidade de escravos era sentida até nos aldeamentos jesuítas e a única forma de evitar a escravização indígena se dava pelo aumento da oferta de escravos africanos.

Não obstante a diversificação e ampliação das possibilidades de domínio sobre os indígenas e africanos, os oficiais da Fazenda de Salvador mostravam, em uma carta à rainha $\mathrm{D}$. Catarina, seu descontentamento pela interferência de Mem de Sá nos resgates. Eles pediam que o próximo governador fosse:

...homem honrado virtuoso e que não seja cobiçoso - e será por nos fazer maior mercê que não possa na terra resgatar senão mantimentos para sua casa por que senão vem com esta condição somos perdidos como estamos por que tomaram todos os resgates do âmbar e escravo ${ }^{18}$.

Nessa carta a figura do governador aparece como concorrente, que utiliza de suas prerrogativas políticas para se apropriar pessoalmente do resgate de escravos em detrimento do povo, que merecia o proveito deste porque «ganhou a custa de seu sangue e trabalho», ao contrário do governador que, com as «mãos lavadas», se apropriava do suor de trabalhos alheios ${ }^{19}$. As críticas dos oficiais mostravam o impacto da instituição do governo-geral nas relações de poder, definidas pelo controle das formas de domínio sobre os indígenas. Os oficiais da Fazenda sugeriam que o provedor da Bahia, ou o escrivão, assumisse o cargo de provedor-mor e reclamavam também dos grandes poderes concedidos ao ouvidor-geral, sugerindo o estabelecimento de um Desembargo, formado por cinco juízes ordinários que despachariam com o governador. A proposta, recuperada no reinado de Felipe II e implementada no de seu filho, visava fortalecer a estrutura judiciária no ultramar e mostrava a influência das reais audiências indianas.

Mem de Sá, da sua parte, entendia que o Brasil não podia se regular pelas mesmas leis e estilos do reino, ressaltando que o governador e o ouvi-

${ }^{17}$ Carta do padre Manuel da Nóbrega ao padre Miguel de Torres, 2 de setembro 1557, Leite, 1954, vol. II: 411.

18 "Carta dos oficiais da fazenda de Salvador, 24 de julho de 1562", ABNRJ (1906): 241.

19 Observa-se o contraste entre a memória produzida pelo governador em seus «Instrumentos», por seus opositores e pela historiografia. Encontro um paralelo interessante na figura de Pedro de la Gasca, «pacificador» do Peru, mas também acusado de agir segundo inclinações personalistas. Ver Merluzzi, 2006: 101-102. 
dor deveriam ter muito mais poder e jurisdição para castigar e perdoar ${ }^{20}$. O governador também indicava que as capitanias de Porto Seguro, Ilhéus, São Vicente e Espírito Santo deveriam ser tiradas de seus capitães e entregues a pessoas honradas. Mem de Sá ressaltava que a maioria das guerras contra os indígenas foi financiada por ele, argumento econômico que justificativa suas ações e apropriações privadas. Assim, o instrumento de serviços procurava conciliar os aspectos privados de sua ação com a representação política da autoridade régia.

As guerras sistemáticas promovidas por Mem de Sá, em grande parte aprovadas pela $\mathrm{Coroa}^{21}$, contra uma diversidade de grupos indígenas e em pontos estratégicos do litoral brasileiro, mostram a intenção de uma sujeição contundente para consolidação desses pontos de colonização portuguesa. Ao invés de uma guerra de conquista que visava à escravização indiscriminada dos ameríndios -em que os atos de violência estavam disseminados sem que fosse possível a identificação de um comando ou sentido estratégico claro- temos uma guerra de sujeição, comandada pelo governador em nome do rei; o que não desfazia a possibilidade de apropriação individual do butim e a tensão entre o poder privado e a autoridade régia. Essa guerra planejada, para ser eficaz do ponto de vista das relações coloniais, deveria favorecer os diferentes grupos sociais da colônia em formação, por meio da diversificação das formas de domínio e sua delegação aos agentes coloniais, como graça e mercê, segundo os serviços prestados e a condição social dos beneficiários e na lógica do divide et impera, reafirmando a preeminência do rei. O favorecimento da mediação do governador-geral por parte da Coroa realçava a percepção de que a definição das modalidades de sujeição dos indígenas era uma prerrogativa essencial para a caracterização da autoridade régia.

Ao mesmo tempo, a Coroa reconhecia que a ação de Mem de Sá tinha um importante grau de independência em relação aos seus interesses e, antes do fim de seu governo, voltou a intervir nas relações de domínio sobre os indígenas e na organização do governo-geral, estabelecendo um novo momento do processo de colonização atlântica ${ }^{22}$. Esse marco foi definido pela coordenação entre a determinação da conquista de Angola e o despacho da primeira lei

20 “Carta de Mem de Sá, 31 de março de 1560”, ABNRJ (1906): 228.

21 «As medidas do Governador tiveram o apoio total da Coroa. Dona Catarina, a Regente portuguesa, manifestou a Sá o seu contentamento pelo sucesso no Espírito Santo e o incentivou a novas empresas contra os inimigos da Coroa». Thomas, 1981: 76.

${ }_{22}$ O bacharel Afonso, sexta testemunha da folha de serviços de Mem de Sá, esclarece que as guerras em Ilhéus foram motivadas pelos pedidos de socorro do capitão, sendo discutidas em conselho, no qual muitos foram de parecer contrário à guerra, «por não ter poder para lhe resistir [aos índios] e nem todo o poder do imperador». Não obstante, Mem de Sá determinou 
indigenista para o Brasil, assim como pelo reordenamento do governo-geral, por meio da criação das Repartições Norte (com sede em Salvador) e Sul (com a capital no Rio de Janeiro).

A justificativa para a divisão do estado do Brasil em duas partes aparece na seguinte passagem da carta de nomeação de Luís de Brito, governador da Repartição Norte:

Dom Sebastião, etc. Faço saber aos que esta virem que considerando eu como por as terras da costa do Brasil serem tão grandes e tão distantes umas das outras e haver já agora nelas muitas povoações e esperança de se fazerem muitas mais pelo tempo em diante, não podiam ser tão inteiramente governadas como cumpria com um só governador, como até aqui nelas houve, assentei assim para o que convém à conversão do gentio daquelas partes, e se dilatar nelas nossa santa fé, como para mais brevemente se administrar a justiça e elas se poderem melhor defender, e por outros respeitos, de mandar dois governadores às ditas partes, um para residir na cidade do Salvador da capitania da Bahia de Todos os Santos, e outro na cidade de São Sebastião do Rio de Janeiro ${ }^{23}$.

O rei intervinha no principal espaço de poder estabelecido por Mem de Sá durante o seu governo: o Rio de Janeiro e suas conexões com São Paulo, a bacia do rio da Prata, o Paraguai e Potosí. A divisão administrativa mostra a consolidação de povoações, estrategicamente localizadas, e o interesse em aumentar o controle sobre as relações coloniais, enfatizando a importância da questão indígena nesse processo ${ }^{24}$. As guerras de conquista e a escravização indiscriminada da população nativa deviam ceder espaço para a organização política, econômica e administrativa da colônia. A transformação qualitativa da sociedade colonial havia acirrado as disputas entre os agentes e grupos de interesse pela definição das formas de organização e exploração das populações indígenas e foi por meio da intervenção nas relações de domínio que a Coroa procurou caracterizar sua preeminência política.

A «lei sobre a liberdade dos gentios», de 1570, foi justificada pelas informações de escravização ilegal dos índios, o que causava grandes inconvenientes às consciências dos que assim os cativavam, ao serviço do rei e de Deus, e ao bem e conservação do «estado das ditas partes». A relação com os indí-

\footnotetext{
ir por sua conta, com «muito pouca gente» - contra o poder Tupiniquim e sem autorização do «imperador». "Instrumentos dos serviços de Mem de Sá", ABNRJ (1906): 167-168.

${ }_{23}$ Carta de nomeação a Luís de Brito, 10 de dezembro de 1572, Varnhagen, 1978, vol. I: $358-359$.

${ }^{24}$ A divisão do estado do Brasil coincide com a criação do colégio dos jesuítas no Rio de Janeiro e revela uma atitude deliberada tanto da Coroa como da Companhia de Jesus de consolidar essas áreas de povoamento, definindo seus centros administrativos.
} 
genas se definia como um elemento central para o estabelecimento do poder político no espaço ultramarino. A lei diferenciava os índios livres e aqueles que podiam ser escravizados - prisioneiros de guerras justas (com licença do rei ou do governador-geral), aqueles que atacassem os portugueses e os que praticassem a antropofagia, como os «Aimorés e outros semelhantes». Os índios escravizados deveriam ser declarados nos livros da provedoria em dois meses, caso contrário,

...hei por bem que percam a alçada dos ditos cativos e senhorio e que por esse mesmo feito sejam forros e livres e os gentios que por qualquer outro modo ou maneira forem cativos nas ditas partes declaro por livres e que as pessoas que os cativarem não tenham neles direito nem senhorio ${ }^{25}$.

A lei estabelecia que os índios estavam sujeitos preferencialmente à jurisdição e ao senhorio do rei, retirando-os dos âmbitos de domínio doméstico e senhorial dos moradores. O governador, o ouvidor-geral, os capitães, os ouvidores e oficiais de justiça deviam fazer cumprir essa determinação ${ }^{26}$. A afirmação das prerrogativas régias em relação ao domínio sobre os indígenas revela a evolução da lei em relação ao que estava definido nas cartas de doação das capitanias e no regimento de Tomé de Sousa. O rei procurava controlar a escravização indígena por meio de instrumentos político-jurídicos, pelo controle da guerra justa ${ }^{27}$-com a concessão de escravização de uma nova etnia- e pela restrição dos resgates ${ }^{28}$ aos «índios de corda». A lei definia as situações jurídicas dos indígenas por meio de um sistema social tripartite -livre, forro ou escravo-, mas silenciava sobre seu estatuto político, a condição de «natural» não implicava na de «súdito», qualificação presente na legislação das Índias Ocidentais, por isso a utilização do termo «gentio». A lei tampouco fazia referência às formas de administração dos aldeamentos.

A lei de 1570 sofreu resistência por parte dos moradores, particularmente no que se referia à tentativa da Coroa de controlar o resgate, a guerra e a escravização dos indígenas. Em sua reformulação, de 1574, destacou-se a

${ }^{25}$ Lei sobre a liberdade dos gentios, 20 de março de 1570, Thomas, 1981: 221-222.

${ }^{26} \mathrm{O}$ governador deveria publicar a norma em todas as capitanias e povoações, com registro nos livros de Chancelaria, Câmara, Desembargo do Paço, Relações e Casas da Suplicação e do Cível.

27 Ver Monteiro, 1994: 41-42.

${ }^{28}$ No Brasil a palavra «resgate» passou a designar os métodos, muitas vezes enganosos, para aquisição de escravos capturados em guerra contra os seus inimigos naturais e comprados pelos colonos. O «resgate de índios de corda» referia-se à escravização dos índios que seriam comidos em um ritual de antropofagia. 
participação dos jesuítas, do ouvidor-geral Fernão da Silva e dos governadores Luís de Brito e Antônio Salema (Repartição Sul). A reformulação procurava estabelecer um consenso colonial em torno da questão indígena no Brasil, como um pacto que representava a vontade do povo diante do rei, restaurando o resgate e a possibilidade das autoridades locais -capitães, Câmara e jesuítasdeterminarem expedições punitivas, guerras justas e «descimentos», mesmo que definindo algumas restrições a essas práticas. Nela, os índios considerados ilegalmente escravizados eram colocados na condição de forros, uma importante diferenciação da lei de 1570 que os considerava livres. Essa condição social enfatizava o lugar subalterno ocupado pelos índios naquela sociedade e justificava a diversificação das formas de domínio que seriam partilhadas pelas instituições e agentes coloniais. No entanto, os eventos que se seguiram evidenciaram a dificuldade de realizar esse pacto colonial e acentuaram as divergências existentes em torno da forma de assentamento e inserção dos indígenas àquela sociedade.

O processo político, entre a determinação régia e a reformulação colonial, representava o trâmite natural das deliberações político-jurídicas da época, daí meu desacordo com a percepção de um recuo por parte da Coroa em relação a sua política indigenista, como afirma Georg Thomas ${ }^{29}$. É possível igualmente questionar a ideia de que o direito costumeiro se sobrepunha à preeminência régia, afinal o rei determinou que as decisões da Junta valessem por três anos, podendo revogá-las a qualquer momento. Além disso, é importante observar que a «questão indígena» se transforma em uma tópica que legitima a intervenção régia, que se manifesta como poder de exceção, ou potestas extraordinaria, para restaurar uma ordem supostamente ameaçada e o princípio legitimador do domínio colonial, a evangelização ${ }^{30}$.

Enquanto os colonos reafirmavam a legitimidade dos resgates no Brasil, por meio das experiências na Guiné, e punham os índios escravizados em uma condição semelhante aos africanos (daí a expressão «negros da terra»), o rei procurava diferenciar essas formas de escravização. No Brasil, espaço de domínio político-jurídico da Coroa portuguesa, a escravidão, como instituição, precisava ser controlada pela autoridade política, por meio da qualificação da guerra e da restrição do resgate.

O quadro de referências das relações de domínio sobre os indígenas e africanos se complementava com as formas de sujeição estabelecidas nas Índias Ocidentais, conformando um campo unificado de experiências que

29 Thomas, 1981: 107.

30 Puntoni, 2009: 46. A importância das tópicas me foi sugerida pelo trabalho de Hansen, 2004: 52. 
vinculava o Brasil, a África e as Índias Ocidentais ${ }^{31}$. Nas palavras do padre Manuel da Nóbrega:

...sujeito e metido no jugo da obediência dos cristãos, para se neles imprimir tudo quanto quisessemos, porque é ele de qualidade que domado se escreverá em seus entendimentos e vontade muito bem a fé de Cristo, como se fez no Peru e Antilhas ${ }^{32}$.

A colonização do Brasil era ainda recente se a compararmos com o processo espanhol, em que a conquista foi desencadeada pela descoberta de metais preciosos. A existência de estruturas político-sociais mais centralizadas entre os indígenas das Índias Ocidentais, a organização do trabalho e da tributação, bem como o conhecimento e exploração das minas anterior à chegada dos europeus, exigiram uma atuação rápida da Coroa na definição dos mecanismos de domínio sobre os indígenas e suas terras. No caso português, as dificuldades em estabelecer um sistema de domínio político e laboral -dadas as especificidades da organização das sociedades indígenas- exigiam uma legislação mais lacunar, que favorecesse o desenvolvimento de mecanismos variados de dominação, relacionados aos objetivos produtivos de cada região e as particularidades das sociedades aí existentes.

\section{Causa bélica, pacificação e governo no Peru}

O início da década de 1570 também foi um momento decisivo para a reconfiguração das relações de domínio sobre as sociedades indígenas e, consequentemente, para a definição da soberania castelhana sobre a América. O novo marco institucional foi estabelecido pelas Ordenanzas de descubrimiento, nueva población y pacificación de las Indias, de 1573. Mas, antes que esse novo estatuto fosse definido, era necessário consolidar a presença espanhola nas principais regiões das Índias Ocidentais, particularmente no Peru e em relação aos incas.

Nesse contexto, e de forma semelhante ao que ocorrera no Brasil, observa-se a sucessão entre as guerras de sujeição, a reconfiguração das relações de domínio e o estabelecimento de um novo marco jurídico-institucional. Em

${ }^{31}$ Georg Thomas considera que as formas de administração das aldeias por chefes indígenas, colonos e capitães leigos relacionavam-se aos modos de trabalho forçado índio próximos ao servicio personal das Índias Ocidentais. Thomas, 1981: 112.

${ }^{32}$ Carta do padre Manuel da Nóbrega a Tomé de Souza, 5 de julho de 1559, Monteiro, 1994: 41. 
relação à autoridade inca, a política espanhola variou entre a definição de uma guerra justa e a tentativa de neutralização de seu poder, por meio do «descimento» do inca para Lima e seu enquadramento à lógica colonial espanhola. Depois da resistência armada, Manco Inca estabeleceu-se em Vilcabamba. Seu filho, Sayre Tupa, em acordo com os espanhóis, fixou residência em Lima em troca da encomienda de Yucay. Com a morte de Sayre Tupa, a ameaça espanhola passou a pesar sobre seu irmão e sucessor, Titu Cusi: deslocamento e abdicação do poder ou guerra justa ${ }^{33}$.

$\mathrm{Na}$ real cédula de 29 de novembro de 1563, Felipe II recomendava ao licenciado Lope García de Castro que atraísse Titu Cusi para Lima oferecendo-lhe uma renda adequada. Quando as negociações pareciam encaminhar-se para uma solução, surgiram acusações de que Titu Cusi teria assassinado seu irmão e fomentava insurreições no Chile, em Tucumán e entre os juries e diaguitas contra «Dios y contra tu rey, y tienen tratado y concertado de alzarse con el reino». Felipe de Segovia, encomendero de Jauja, acusou o inca de ter «um bohío muy grande cubierto de paja» em que se trabalhava ativamente na fabricação de armas, «y ser como sois pocos y los indios tantos y tan bien armados: entrarán publicando libertad a los mestizos y esclavos» ${ }^{34}$. Titu Cusi parece ter tomado todas as medidas para evitar um incidente que desse aos espanhóis um casus belli - aceitando a entrada de missionários, de um corregedor, convertendo-se ao cristianismo, impedindo as agressões aos espanhóis e omitindo as riquezas minerais da região. Mas recusava-se a sair de Vilcabamba.

$\mathrm{Na}$ Corte, a associação entre três homens eminentes levaria a decisão pela guerra. O cardeal Diego de Espinosa, presidente do Conselho de Castela (1565) e inquisidor-geral (1566), encabeçava o grupo, tendo sido responsável pelas nomeações de Francisco de Toledo, como vice-rei do Peru, e de Juan de Ovando, para a presidência do Conselho de Índias. A posição de Espinosa, favorável à guerra contra os incas, se construiu a partir de experiências domésticas, europeias e imperiais de dominação e soberania que se articulavam naquele momento histórico. No verão de 1566, o Conselho de Estado, do qual Espinosa fazia parte, enviou o duque de Alba, primo de Francisco de Toledo, para combater a rebelião protestante nos Países Baixos. Diante do fortalecimento turco no Mediterrâneo e das rebeliões «mouriscas» em Granada, Espinosa, à frente do Conselho de Castela, determinou a expulsão e dispersão dos «mouriscos». Nas palavras de Catherine Julien: «o uso da força

\footnotetext{
${ }^{33}$ Julien, 2007: 243-244.

${ }^{34}$ Carta de Felipe de Segovia Briceño de Balderrábano al gobernador García de Castro, 3 de dezembro de 1564, Hemming, 2000: 361-364.
} 
e a remoção de um povo que resistia à incorporação na sociedade espanhola cristã foi precursor do que Toledo planejava para Vilcabamba» ${ }^{35}$.

Enquanto a articulação entre as medidas tomadas para o império português partiram da Mesa de Consciência e Ordens, no caso espanhol, elas foram deliberadas pela Junta Magna, também sob a direção de Diego de Espinosa ${ }^{36}$. Mesmo que as posições de Felipe II e do papa Pio V, tanto para o caso de Granada como para a América, recomendassem moderação, elas deixavam a via bélica aberta para a decisão de seus representantes. Francisco de Toledo, em articulação com Espinosa, partiu com a intenção de fazer guerra contra Titu Cusi e mobilizou os meios para a produção de uma memória que a legitimasse $^{37}$. Por fim, a posição estratégica assumida por Diego de Espinosa só foi possível pelo apoio do rei.

A campanha do vice-rei D. Francisco de Toledo contra Túpac Amaro, que sucedera Titu Cusi depois de sua morte, foi justificada pelas «embaixadas frustradas» de Gabriel de Oviedo e de Atilano de Anaya e pelo martírio do frei Diego Ortiz. A passagem da década de 1560 para a de 1570 está marcada pela utilização dos martírios e das «embaixadas frustradas» como justificativa das guerras de conquista. Em Monomotapa, pelo martírio do padre Gonçalo da Silveira. Em Angola, como veremos em seguida, na embaixada de Paulo Dias de Novais e pela prisão e morte do jesuíta Francisco de Gouveia. Houve planos mais ambiciosos, como a legitimação das conquistas do Egito, motivada pelo cativeiro de Fulgêncio Freire, e da China, mas, nesses casos, o poderio militar europeu era insuficiente. A semelhança e a coordenação entre esses diferentes projetos de conquista indicam uma premeditação, no intuito de expandir o domínio cristão em escala global. Nas ideias de «embaixadas frustradas» e de martírio se define uma tópica legitimadora da ação bélica para o estabelecimento de espaços de domínio europeu. Como no caso da América

35 Julien, 2007: 252.

${ }^{36}$ Tenho pouca informação documental sobre a forma de deliberação da Mesa de Consciência e Ordens em relação à determinação de conquista de Angola e as leis indigenista no Brasil. Levanto a hipótese, a ser confirmada em investigações subsequentes, de que se estabeleceu uma comissão especial, seguindo o modelo de juntas. Essa hipótese chama a atenção para as transformações ocorridas na forma de governar em Portugal antes de sua incorporação à monarquia Habsburgo. Proponho que essas transformações são mais o resultado do estabelecimento de um campo unificado de experiências de dominação e soberania entre Castela e Portugal, do que, na perspectiva de António M. Hespanha, de uma «modernização» resultante de uma «forma espanhola de Poder». Ver Hespanha, 1989: 51 e ss.

37 A Historia Indica, de Pedro Sarmiento de Gamboa, encomendada por Toledo, questionava a autoridade inca e legitimava sua sujeição à Coroa castelhana. Além desta obra, é preciso destacar o tratado Parecer de Yucay, atribuído ao frei García de Toledo, primo do vice-rei, que refutava as teses de Bartolomé de las Casas. Mumford, 2011: 50-52. 
portuguesa, trata-se de uma guerra de sujeição comandada pelo representante do rei, mesmo que a condução da guerra implique em algum descontentamento por parte da autoridade régia.

No Peru, o destacamento dos vice-reis como mediadores privilegiados das formas de exploração sobre os indígenas foi definido pela atuação de D. Francisco de Toledo. Dentre as medidas tomadas por ele, destaca-se a primeira visita completa que um vice-rei fez por todo o Peru, empreendida a partir de outubro de 1570 . Toledo organizou o sistema de mita mineira, que foi sancionado pela Coroa.

Na síntese de Steve Stern:

Para resolver el problema de mano de obra de los colonizadores, Toledo estableció un sistema de leva de mano de obra basado en las cifras tributarias. Tradicionalmente, la sociedad indígena complementaba el trabajo colectivo de la comunidad como un todo mediante un sistema de rotación. Los campesinos servían una mit'a o turno de los trabajos totales de la comunidad. Las rotaciones permitían a las comunidades y a los ayllus distribuir las necesidades o las obligaciones de trabajo colectivo conforme a las reciprocidades locales, que exigían contribuciones iguales de tempo de trabajo por los grupos de parentesco de la comunidad. Los incas ampliaron las tradiciones locales de mit'a como medio de extraer fuerza de trabajo que, como siempre, trataba de atribuir a las cargas de los campesinos el carácter de costumbres conocidas de la vida comunitária. Toledo transformó la tradición de la mit'a en una institución colonial de trabajo forzoso ${ }^{38}$.

A Coroa se mostrava favorável à utilização desse sistema na mineração, mas procurou restringir a mita e a yanacona na agricultura ${ }^{39}$. O objetivo dessa restrição era interferir nas formas de dominação senhorial e doméstica estabelecidas pelos colonizadores espanhóis, ou pela mediação com os kurakas, puxando as relações de vassalagem e tributação para o âmbito da Coroa e da mediação dos funcionários régios. Esse foi o principal feito das reformas

38 Stern, 1982: 136. Adoto a diferenciação de Stern do termo «mit'a» para referir-se à instituição tributária-laboral andina e «mita» para o sistema de dominação do colonialismo espanhol.

39 Assim como a mita, é interessante diferenciar os «yana», para referir-se ao período pré-hispânico, dos «yanacona», para tratar da época colonial. Os «yana», na época incaica, segundo John Murra, estavam «exentos de las prestaciones rotativas (...). Todos habían perdido su condición de campesinos, miembros de un grupo étnico y de parentesco; ya no se les enumeraba en el quipu, y formaban parte del creciente sector de la población que recebía su sustento completo de los depósitos del estado, pues dedicaba todo su tiempo a éste». Murra, 1978: 245 e ss. No Thesaurus Indicus, de Diego de Avendaño, «Hay entre nuestro occidentales unos llamados Yanaconas, voz que significa Servidores, que se dedican a varios tipos de trabajo». Apud Cuena Boy, 2006: 11, n. 6. 
de Toledo que, ao eliminar a autoridade inca, reestruturou o sistema de mita, estabelecendo as obrigações de tributo e trabalho na relação direta entre os kurakas e a autoridade régia ${ }^{40}$. As formas de dominação doméstico-senhorial continuaram existindo, mas agora estavam mais claramente subordinadas à vontade e à graça régias. Em relação aos yanaconas, Toledo rejeitou sua liberação, mas instituiu legalmente o sistema, que se expandiu, motivado pela resistência indígena das obrigações da mita. No médio prazo, a passagem de mitayo a yanacona, como analisa Steve Stern, levou à desagregação das identidades e dos vínculos de parentesco e políticos andinos, reforçando o sistema de dominação colonial.

Outra medida, discutida em 1574 e relacionada a tentativa de diminuir a pressão sobre os indígenas, foi transformar o tráfico de escravos africanos em monopólio régio para vendê-los aos colonos, que explorariam as minas das Índias Ocidentais e desenvolveriam a agricultura, tanto para o mercado interno como externo ${ }^{41}$. Em sentido semelhante, a Coroa determinou que os «espanhóis vagabundos e ociosos e os mestiços, negros, mulatos e zambaigos livres» fossem compelidos ao trabalho.

As medidas tomadas por Francisco de Toledo, entre o reconhecimento das demandas dos encomenderos e as determinações da Coroa, tinham uma importante marca personalista, que o deixava em uma posição de poder entre os interesses locais e os da Coroa. Segundo o cronista Guaman Poma de Ayala:

Cómo don Francisco de Toledo se enojó muy mucho contra Topa Amaro Inga porque le habían informado que había dicho el Inga como muchacho y con razón, cuando le envió a llamar dijo que no quería ir a un mayordomo de un señor inga como él. Y de esto hubo odio y sentencia de muerte de enojo contra el Inga, y lo sentenció a cortarle la cabeza a Topa Amaro Inga. ¡Oh cristiano soberbioso que habéis hecho perder la hacienda de su Majestad, de los millones que daba la ciudad y los tesoros escondidos de sus antepasados y de todas las minas y riquezas ha perdido su Majestad por quererse hacerse más señor y rey don Francisco de Toledo, no sáis como él ${ }^{42}$.

O rei espanhol voltou, então, a interferir nas questões coloniais, reafirmando sua autoridade acima da condução política de seu representante, e a

40 Spalding, 1984: 168 e ss. Monteiro, 2006, vol. 1: 201 e ss.

${ }^{41}$ Segundo Frederick Bowser, a importação de escravos africanos para as minas se tornou uma alternativa real durante a década de 1550. No vice-reinado de Francisco de Toledo foi estabelecida uma legislação que obrigava os negros e seus descendentes livres a trabalhar nas minas em troca de um salário. Com a união das Coroas em Felipe II essa alternativa foi estimulada. Bowser, 1977: 44-47.

${ }^{42}$ Poma de Ayala, 2005, vol. II: 347-348. 
execução de Tupac Amaro lhe serviu como pretexto. A Coroa condenou os excessos do vice-rei e o deixou em situação incômoda para quem reconhecia em suas ações o desejo imperativo de servir ao rei e esperava o reconhecimento de seus serviços.

Definidas as formas básicas de dominação sobre as populações nativas e a conquista do último reduto inca, a Coroa passou a definir um novo marco de seu domínio sobre a América. Assim como no caso brasileiro, só que com um sentido político-jurídico muito mais evidente, a «questão indígena» justificou a intervenção régia. O jurista Juan de Ovando foi o responsável por esse novo marco político ${ }^{43}$.

Depois de um profundo estudo sobre a «legislação indiana», que deu início à sua compilação, propôs uma ampla reforma no Conselho de Índias, aprovada em 1571, e passou a presidi-lo. Ovando, no projeto para as Ordenanzas de 1573, assim define a legitimidade do domínio castelhano:

Todos los indios naturales del Estado de las Indias son nuestros vasallos y de nuestra jurisdicción, imperio y señorío, así por la concesión que de ello tenemos, como por la justa adquisición que de ellos hemos hecho, por descubrimiento los haber descubierto y hallado, apprehendido y adquirido al gremio de la santa Iglesia en lo spiritual y a nuestro Reino en lo temporal, en todas las partes de las dichas Indias, y en tantas y tan grandes partes de ellas, que suficientemente tenemos ya adquirido derecho en todo el Estado de las Indias ${ }^{44}$.

O primeiro título era o da concessão papal, o segundo, de descobrimento, e o terceiro era a realização justa da subordinação espiritual e temporal das Índias e dos ameríndios. Alfonso García-Gallo, em seu artigo "Las Indias en el reinado de Felipe II: La solución del problema de los justos títulos" 45 , se pergunta: por que Carlos V não resolveu essa questão de legitimidade na sequência do debate entre Las Casas e Sepúlveda? A resposta está nesse trecho de Ovando. Somente na década de 1570, com o golpe final contra os incas, se define esse domínio como direito adquirido, em que a jurisdição, o império, o senhorio régio e o poder espiritual estão presentes nas diferentes partes daquele «Estado». A soberania régia sobre as Índias Ocidentais emerge como indivisível e inalienável.

Nas Ordenanzas, a «conquista», caracterizada como iniciativa privada, deveria ser descartada do léxico e das práticas coloniais. As novas empresas de ocupação territorial e subordinação dos indígenas deveriam ser caracterizadas

\footnotetext{
${ }^{43}$ Poole, 2004.

${ }^{44}$ Apud García-Gallo, 1972: 444.

45 Ibidem: 425 e ss.
} 
como «pacificação». A tinta e o papel construíam uma soberania imaginada, em que a autoridade do rei se impunha sobre o poder privado e senhorial dos vecinos. Nesse contexto, a ampliação do tráfico de africanos era uma estratégia central para a reafirmação do poder das Coroas nas Américas e para o incremento do comércio colonial. A necessidade de mão de obra nas Índias de Castela e a importância estratégica, política e militar, dos negros aumentavam a demanda e exigiam uma nova etapa do comércio de escravos ${ }^{46}$. Felipe II, em 1566, estabeleceu contatos com a Coroa portuguesa a fim de ampliar esse tráfico e, em 1574, pretendia colocar esse comércio sob monopólio régio ${ }^{47}$.

Angola era a porção continental privilegiada para esses planos, possuía uma estrutura político-militar menos organizada que a do Congo e se mostrara uma fonte aparentemente inesgotável de escravos. A decisão de conquistar Angola aparece, assim, como estratégia comum para os reis português e espanhol na construção de um império ultramarino atlântico.

\section{Conquista, vassalagem e ESCRAVIDÃo EM ANGola}

O projeto de «conquista de Angola» foi aceito por D. Sebastião, depois das experiências frustradas de embaixadas de Paulo Dias de Novais e da prisão e morte do jesuíta Francisco Gouveia. Assim como no caso inca, temos a ideia de «embaixada frustrada» e de martírio de um missionário como causa bélica. A empresa, solicitada por Paulo Dias de Novais, contou com o apoio dos jesuítas e de autoridades representadas na corte de D. Sebastião.

D. Sebastião etc. Aos que esta minha carta virem faço saber que vendo e considerando eu quanto convém a serviço de nosso Senhor e também ao meu mandar sujeitar e conquistar o Reino de Angola, assim para se nele haver de celebrar o culto e ofícios divinos e acrescentar a nossa Santa fé católica e promulgar o Santo Evangelho, como pelo muito proveito que se seguirá a meus Reinos e Senhorios e aos naturais deles de se o dito reino de Angola sujeitar e conquistar ${ }^{48}$.

A determinação da conquista e sujeição do reino de Angola é um fato inédito na expansão atlântica portuguesa, somente comparável às conquistas

${ }^{46}$ Frederick Bowser destaca a importância dos negros na América espanhola: nas guerras coloniais; como mão de obra para agricultura; para o sistema de transporte; e para a navegação e o comércio de produtos pela costa do Pacífico. Bowser, 1977: 131-140 e 165.

${ }^{47}$ Cf. Godinho, 1983, vol. 4: 170 e ss.

${ }^{48}$ Carta de doação a Paulo Dias de Novais, 19 de setembro de 1571, Brásio, 1953, vol. III: 36 . 
do Peru e do México promovidas pelos espanhóis. De uma posição de reconhecimento dos poderes africanos e de uma política de influência baseada no apoio militar e na conversão religiosa com fins mercantis, a Coroa, estimulada pela expansão do mercado escravista nas Américas, delegou a Novais uma empresa de conquista e sujeição.

A «conquista de Angola» se justificava pelo serviço de Deus e do rei, para o bem de seus reinos e senhorios e de seus súditos. Para legitimá-la eram evocadas as bulas apostólicas concedidas aos reis passados, reforçando os direitos determinados nas doações papais. No entanto, a carta de doação não especifica os motivos que levaram à determinação de conquista. Os títulos que parecem estar de acordo com ela foram o de impedimento, por parte do Ngola, de promulgação da fé católica em seu reino, principalmente depois da prisão do padre jesuíta Francisco Gouveia, ou de ruptura com um suposto pacto de aliança entre o Ngola e o representante português, Paulo Dias de Novais.

O órgão responsável por essa decisão foi a Mesa de Consciência e Ordens que, no mesmo momento, havia despachado a primeira lei indigenista para o Brasil. A carta de doação a Paulo Dias incorporou diferentes experiências de domínio ibérico sobre o ultramar: as doações papais, o modelo de doação de capitanias portuguesas e as experiências de subordinação de reinos ou impérios na América espanhola.

Embora o significado da doação de Angola fosse muito distinto do das capitanias de São Tomé e do Brasil -conquista, em vez de descobrimento e povoamento- elas serviram de modelo para sua redação ${ }^{49}$. Os serviços prestados por Paulo Dias em Angola, a disposição de conquistar o reino a sua custa $^{50}$ e a memória dos feitos de seu avô, Bartolomeu Dias, justificavam a doação. Seguia-se a mesma fórmula usada nas doações de capitanias em São Tomé e no Brasil: «de meu moto próprio, certa ciência, poder real e absoluto».

$\mathrm{O}$ rei doava ao capitão dois espaços distintos de jurisdição. $\mathrm{O}$ primeiro referia-se às terras entre os rios Dande e Cuanza, que eram doadas pela vida de Paulo Dias. O rio Dande foi definido como fronteira norte de Angola, se sobrepondo às reivindicações de soberania do rei do Congo sobre a região. O segundo espaço era a capitania de 35 léguas ao sul do Cuanza, doada de juro e herdade, em que Paulo Dias e seus herdeiros teriam os cargos e honras de capitães e governadores, com poderes jurídicos, direitos econômicos e

${ }^{49}$ Cf. Schwartz, 2011: 38.

${ }^{50}$ Segundo Jerônimo de Castanho, Paulo Dias de Novais não tinha bens suficientes para patrocinar a conquista, tendo buscado seu apoio financeiro e o de Jorge da Silva por meio dos padres da Companhia de Jesus. Memórias de Jerónimo Castanho a El-Rei, 5 de setembro de 1599, Brásio, 1954, vol. IV: 606. 
de distribuição de sesmarias semelhantes aos dos donatários brasileiros - o capitão tinha direito a enviar 48 escravos isentos de tributos por ano, com a obrigação de seguirem a Lisboa, os restantes pagariam mil e seiscentos réis por «peça». Paulo Dias tinha o direito de escolher 20 léguas de terras livres e isentas, «repartidas em quatro ou cinco partes e não sendo de uma a outra menos de duas léguas». Acrescentava, em relação às doações do Brasil, a condição de serem aproveitadas em quinze anos, «e não o cumprindo assim ficarão as ditas terras livremente a mim para poder delas fazer o que for meu serviço» ${ }^{51}$.

Além dessa última condição, é de se notar que a Coroa reservava para si a região mais importante do comércio de escravos e de nzimbos (conchas retiradas principalmente da ilha de Luanda e que serviam como moeda no Congo e Angola). Com a morte de Paulo Dias seria mandado um governador e oficiais de justiça para essa parte, explicitando, no conteúdo da doação, que as capitanias representavam uma etapa inicial de povoamento que deveria ser sucedida de uma intervenção político-administrativa por parte da Coroa. As obrigações de Novais eram: levar um galeão, duas caravelas, cinco bergatins e três muletas, para explorar até o Cabo da Boa Esperança; além de quatrocentos homens para a guerra, de mantimentos para sustentar todos por um ano; não levar cristãos-novos; fazer três castelos em dez anos (com determinação da localização de um deles, tamanho e material, podendo demorar um pouco mais com a autorização do rei); em três anos deviam ter, ao menos, vinte éguas e cavalos; em seis anos estabelecer na capitania cem moradores com suas mulheres e filhos, lavradores com sementes do Reino e de São Tomé. Correndo tudo a sua custa. No fim do documento o rei acrescentava outras obrigações: levar três padres e o necessário para os cultos; fazer uma igreja para São Sebastião e outras igrejas; e ainda, os escravos deveriam ser justificados conforme o regimento passado pela Mesa da Consciência para São Tomé.

As regras de sucessão e herança eram iguais às das capitanias brasileiras e também não podiam ser embargadas pela Lei Mental. Apesar das amplas concessões presentes no documento, a suspensão da doação poderia ser determinada pelo rei, e os privilégios escravistas foram restringidos. Além disso, as condições da doação eram extremamente difíceis de serem cumpridas.

A expedição partiu de Lisboa no fim de 1574, desembarcando em Angola no ano seguinte. O conflito teve início, segundo as fontes portuguesas, quando o ngola [em itálico] ${ }^{52}$ mandou matar todos os portugueses de sua cidade, em

\footnotetext{
${ }^{51}$ Carta de doação a Paulo Dias de Novais, Brásio, 1953, vol. III: 41.

${ }^{52}$ Heintze, 2007: 182.
} 
$1579^{53}$. Este evento foi a causa para o início das ações bélicas portuguesas. Ao invés de considerar o período de 1575 a 1580 como de uma «parceria instável» entre o governador e o Ngola, entendo-o como de preparação da conquista e das estratégias de guerra. Ou seja, como no caso de D. Francisco de Toledo, havia uma predisposição para a guerra anterior à partida de Portugal e desde a chegada foram mobilizados os recursos materiais e preparados os discursos legitimadores dessa solução.

As ações militares, movidas por forte sentimento religioso ${ }^{54}$, não tiveram tréguas e visavam às minas de prata de Cambambe, à tributação dos chefes nativos e aos escravos para o mercado americano. No processo de conquista, o governador e os capitães doaram os sobas a particulares e jesuítas por meio de um sistema de domínio senhorial, denominado «amos». Os sobas eram doados em pagamento aos serviços prestados na conquista e, de acordo com o estatuto social do beneficiário, cabia a este «protegê-los» e cristianizá-los em troca do pagamento de tributos, pagos em escravos.

Segundo o historiador Alberto da Costa e Silva,

[Paulo Dias de] Novais resolveu aplicar esse sistema de tutela aos nativos que a ele se aliavam ou se submetiam (...). A cada soba, chefe de aldeia ou cabeça de linhagem o donatário deu um 'amo' português, que pronto se transformou em amo, em mais do que patrão, em senhor. (...) Era de se esperar que essa gente interpretasse a tutela como um senhorio: o soba lhe havia sido doado para seu serviço e, em última análise, pertencia-lhe, com todos os seus dependentes ${ }^{55}$.

As características elencadas acima e as tensões políticas decorrentes da disputa pelo domínio dos sobas entre a Coroa e os agentes coloniais aproximam o «sistema de amos» angolanos ao das encomiendas americanas ${ }^{56}$.

${ }^{53}$ História da residência dos padres da Companhia de Jesus em Angola, e coisas tocantes ao Reino, e conquista, 1 de maio de 1594, Brásio, 1954, vol. IV: 572-573.

${ }^{54}$ Diz o padre Baltasar Barreira: «Deus lhe fizera guerra e os pusera em fugida; e assim é corrente na terra que anda com os nossos chamar à guerra dos portugueses, guerra do Céu e de Deus». Carta do padre Baltasar Barreira para o Provincial, 20 de novembro de 1583, Albuquerque, 1989: 124-127.

55 Silva, 2002: 417.

56 Parece-me importantíssimo recuperar os estudos comparativos entre os diferentes sistemas de domínio senhorial anteriores à presença europeia nas Américas e na África subsaariana, procurando entender as transformações dessas «instituições» decorrentes do colonialismo ou do escravismo europeu. Nessa perspectiva, a seguinte observação de John Murra me chama a atenção: «Todavía me acuerdo de la exaltación que acompañó el descubrimiento de que la dopkwe dahomeiana era parecidísima a la mit'a incaica». Murra, 1978: 13. 
As questões relativas à legitimidade do domínio se colocaram, em Angola, a partir do momento da determinação de sua conquista. $O$ primeiro aspecto desse problema era a legitimidade da guerra e do domínio do rei português sobre o Ngola e seu reino. O segundo referia-se ao domínio dos conquistadores e jesuítas sobre os sobas. Em terceiro lugar, colocavam-se as questões relativas à legalidade do comércio de escravos, ao monopólio português e ao envolvimento dos jesuítas neste trato. A elaboração dos discursos de legitimação teve início paralelamente ao processo de conquista. Em relação a esse primeiro nível de domínio, diz o padre Baltasar Barreira em sua "Informação acerca dos escravos de Angola":

Este reino de Angola começou no bisavô do que agora reina, porque antes todo era de Senhores particulares, que não reconheciam ninguém sobre si. E como isentos e livres de toda sujeição, defendiam suas terras e faziam guerra a quem os agravava. E acrescentavam seus limites à força de armas, como fez o primeiro Rei, que sendo Senhor particular como cada um deles, os sujeitou a todos, mas de tal maneira que ficaram Senhores das terras que antes possuíam, pagando seus tributos ${ }^{57}$.

Esse trecho, que só com muita cautela pode ser utilizado como fonte de informação etno-histórica, justificava o domínio europeu, atribuindo ao Ngola um domínio recente, adquirido por meio da violência. A aproximação entre os discursos de deslegitimação das autoridades nativas é evidente ${ }^{58}$. $\mathrm{O}$ novo momento da expansão europeia pelo mundo levou a produção de um «conhecimento histórico-etnográfico» que tinha por finalidade questionar a autoridade nativa constituída. No caso peruano, o marco dessa produção é a Historia Indica, de Gamboa, e as visitas e inquirições, comandadas por Francisco de Toledo, além da propaganda pró-colonos, como o Parecer de Yucay. Para o caso

57 Informação acerca dos escravos de Angola, 1582-1583, Brásio, 1953, vol. III: 227.

58 Veja a semelhança da argumentação, quando D. Francisco de Toledo, vice-rei do Peru, comunica aos descendentes dos incas as conclusões de sua inquirição: «les dijo por una lengua (...) que los Incas habían sido señores deste reino y los llamaban ellos: reyes, que no se lo podían decir ni habían sido reyes dél, sino usurpadores». Apud Hemming, 2000: 501. No Parecer de Yucay, «haber sido el Inga uno de los mayores tiranos del mundo y más frescos (...). Porque antes deste tirano no había señor universal ni particular en la tierra, sino que cada uno lo era de su casa», Cortés Rojas, 2011: 110. O historiador Pedro Borges, em sua análise do debate sobre a legitimidade da conquista nas Índias Ocidentais, observa que essa tópica, da ilegitimidade da soberania dos chefes indígenas, foi utilizada de forma generalizada pelos funcionários régios. $\mathrm{O}$ mesmo autor destaca a postura favorável às guerras de conquista por grande parte dos franciscanos no México, entre eles o frei Toribio de Benavente, ou Motolinia, que justificava o domínio espanhol porque os imperadores astecas haviam usurpado o império pela guerra e perpetravam uma série de delitos contra inocentes. Peña, 1982: 22-33. 
angolano, essa foi uma produção jesuíta, que aliava o debate jurídico com a propaganda pró-colonos, e seu principal autor foi o superior Baltasar Barreira.

Em seguida, Barreira definia como costumeira a forma de sujeição senhorial dos sobas e o pagamento de tributos, o que legitimava o domínio dos conquistadores e jesuítas, e passava a analisar a legitimidade do negócio escravista. Começa tratando da ausência de moeda, o que dava às mercadorias um valor de troca, sendo os escravos um produto de destaque. Ao descrever as feiras, discute a legitimidade dos escravos vendidos. A principal ocorria em Cabaça, capital onde vivia o ngola [em itálico], que, segundo Barreira, tinha um funcionário régio que garantia a boa procedência dos escravos, restituindo a liberdade dos injustamente escravizados. $\mathrm{O}$ mesmo procedimento se verificava nas outras feiras, porque todas eram regidas por oficiais do rei. Outra evidência dessa legitimidade se observava pela forte resistência dos que eram injustamente cativos.

No terceiro parágrafo, Baltasar Barreira descrevia a existência de três tipos de «peças» em Angola:

...umas que os Senhores de Vassalos tem em suas terras para as cultivar, nascidos e procriados de outros que seus antepassados tomaram em guerras e fizeram quando não reconheciam superior, outros que eles mesmos tomaram nas guerras feitas com licença de seu Rei, o qual examina as coisas etc. Outros que foram compreendidos em delitos, pelos quais mereciam a morte ${ }^{59}$.

Esses eram os títulos legítimos de escravização - por nascimento, guerra justa e comutação da pena de morte, que respondiam aos problemas de consciência e direito portugueses. O que não era possível era averiguar o título de cada uma das «peças».

...todas estas três sortes de peças andam de feira em feira, e as vendem uns negros a outros, parte para cultivar suas terras, parte para os tributos que pagam a seu Rei, e parte para se ajudarem delas em seus trabalhos e necessidades, vendendoas, ou dando-as, não é possível tirar-se a limpo de que título são, as que os nossos compram. E além disso é coisa de riso entre eles perguntar lhe[s] por isso, nem respondem outra coisa senão que são suas peças, por ser extraordinário o segredo que guardam em suas coisas ${ }^{60}$.

A escravização era justa, mas o título não podia ser confirmado por causa do dinamismo daquele comércio em Angola, profundamente arraigado nas

59 Informação acerca dos escravos de Angola, Brásio, 1953, vol. III: 228.
60 Idem. 
práticas locais e envolto em certo segredo comercial. Daí, concluía o padre, ser aquela guerra e aqueles escravos os mais justos de toda a Guiné.

E a conclusão será, que quanto mais entramos pela terra, e tratamos dos negros, tanto mais experimentamos que de nenhuma parte de Guiné vão peças que se possam comprar mais seguramente que as de Angola. E a todas as coisas sobreditas se ajunta que é muito justa a causa porque os nossos lhe fazem agora guerra ${ }^{61}$.

A informação de Barreira referia-se à legitimidade do domínio português sobre Angola; por ela o padre justificava o domínio político-jurídico do rei português, o domínio senhorial sobre os sobas e o pagamento de tributos, o tráfico de escravos e a participação dos jesuítas. Baltasar Barreira procurava harmonizar um sistema de domínio senhorial hierarquizado - entre o rei, os amos portugueses, os sobas e os escravos- mas, no momento de instituição do governo-geral em Angola, em 1592, assim como ocorrera no Brasil e no vice-reinado peruano, a Coroa vai procurar romper, ou subordinar, com os sistemas de domínio intermédios, revelando as disputas e tensões existentes no processo de colonização e de formação das monarquias modernas ${ }^{62}$.

${ }^{61}$ Idem. Grande parte da argumentação de Baltasar Barreira já estava presente em uma carta, de 1576, do padre Garcia Simões, em que mostrava preocupação em saber como eram cativos os cerca de 14 mil escravos anuais de Angola, que dizia: «houve um Angola grande, que dizem sujeitou toda esta gente por armas donde ficaram eles cativos, e os senhores têm vila e lugares que o mesmo Rei lhes dá com alçada, e sendo-lhes traidores e alevantados os sujeitam, de maneira que os podem matar ou os vendem. Também dizem ser / certo que se se provar que homem compra ou vende pessoa livre será destruído e punido como ladrão, com pena de morte, e que também que as mesmas peças se não são cativas logo reclamam e não se deixam vender». Carta do padre Garcia Simões ao padre Luís Perpinhão, 7 de novembro de 1576, em Brásio, 1953, vol. III: 146.

${ }^{62} \mathrm{O}$ mesmo esforço de harmonização de um sistema hierárquico e senhorial de domínio é feito no Parecer de Yucay em relação às encomiendas perpétuas. Segundo o documento, era a posição de Las Casas em favor do «império soberano» do rei espanhol que colocava em risco a preservação das Índias: «Y de aquí colegía que, no solamente no se podían dar indios en perpetuidad, pero ni aun en encomienda, sino que todos estuviesen en la corona real, porque éstos eran señores naturales. Y hubiera a esta ceguedad de costarle al rey perder las Indias, y el demonio tornar a ganar estas almas. Mas, siendo la verdad ésta: que ellos fueron tiranos y tiránicamente proveyeron estos caciques, como consta que el rey es señor verdadero destos reinos, bien podrá, no solamente encomendar indios por vidas, mas hacer señores perpétuos a españoles como podrían hacer a los mismos indios», Cortés Rojas, 2011: 120-121. 


\section{CONSIDERAÇÕES FINAIS}

A geopolítica de expansão da «república cristã» foi delineada nos documentos pontifícios e das monarquias ibéricas na segunda metade do século XV. A bula Romanus Pontifex, de 1455, estimulava a expansão portuguesa às Índias pela costa africana, legitimando o tráfico dos negros da Guiné e buscando aliar-se aos «índios cristãos» contra o poder muçulmano. Os tratados de Alcáçovas-Toledo, de 1479 e 1480, indicavam a outra rota de expansão, a partir das Canárias, rumo ao Ocidente. As bulas Inter Caetera, de 1493, confirmavam e favoreciam esse caminho, delegando-o aos reis de Castela e Leão. Finalmente, o tratado de Tordesilhas consolidava essa divisão, estabelecendo um enclave português nas terras recém descobertas por Colombo e facilitando, segundo o sistema de correntes e ventos marítimos, a transposição da África às Índias Orientais. A Igreja era o poder espiritual que coordenava a expansão de Castela e Leão pelo Ocidente e a de Portugal pela África. Ainda nesse fim de século, as monarquias ibéricas fizeram uma tentativa de união das Coroas tendo em vista o destacamento do poder real e essa mesma perspectiva geopolítica.

Em meados do século XVI, esse projeto imperial teve que lidar com a abertura de diferentes flancos de batalha. Na Europa Central, contra as monarquias e repúblicas cismáticas, com destaque para os Países Baixos. No Mediterrâneo e na África, contra os poderes muçulmanos e pagãos, em Lepanto, Alcácer-Quibir, Monomotapa e Egito; e, na Ásia, contra Ormuz, Goa e China. As Américas, nesse contexto, se transformaram no novo centro da política imperial católica no mundo. Do Peru e do México se abriram as novas rotas para o Oriente, através das Filipinas. O Brasil, Angola e Moçambique eram a outra conexão com a Índia e a China.

A guerra foi o ponto de partida desse processo. Guerra de conquista somente nos espaços fora do domínio ibérico. Como em Angola, onde a guerra foi delegada ao capitão Paulo Dias de Novais em troca de mercês e privilégios senhoriais. O rei, consciente de que esses poderes delegados faziam emergir novos senhorios, determinava uma série de condições que facilitariam, num futuro próximo, a intervenção nesse novo espaço de jurisdição. A preferência era pela guerra justa decretada pelo príncipe e conduzida por seus representantes. No caso do Brasil, a guerra de sujeição, comandada pelo governador e adaptada às estruturas de poder das sociedades «contra o Estado». No caso do Peru, mirando a experiência mexicana, a guerra contra as «tiranias frescas», conduzida pelo vice-rei como pacificação, buscava a incorporação e sujeição de velhos e novos súditos à Coroa. A legitimidade construída pelos discursos do papa e do rei sugeria moderação, mas deixava a via bélica aberta. Ainda 
nos centros de poder, nas cortes e conselhos, destacavam-se nomes, como o de Diego de Espinosa, que transformaram esses discursos em projetos de ação. $\mathrm{Na}$ expansão ultramarina, o rei ausente delegava o poder da espada aos seus representantes, e não sujava a mão.

$\mathrm{Na}$ guerra de conquista, o domínio sobre as «autoridades naturais» $-k u$ rakas, caciques e sobas e, por meio destas, sobre os «indígenas»- ficava a cargo de amos europeus que, em troca de proteção, salvação e mercadorias, recebiam os tributos e se transformavam em «senhores de vassalos». Esse domínio era o fundamento dos poderes coloniais. Nas guerras de sujeição e pacificação, legitimadas por discursos político-jurídicos e etno-históricos -ou pela propaganda contra a barbárie e a tirania de inimigos internos e externos-, a vassalagem e o tributo deveriam ser diretamente prestados à Igreja e à Coroa, deixando claro que as diferentes modalidades de domínio sobre os «indígenas» eram prerrogativas destes poderes. A guerra de pacificação era seguida pela reconfiguração das relações de domínio e poder, por meio da «legislação indigenista»e do fortalecimento do aparato político-administrativo que representava a soberania régia. $\mathrm{O}$ rei era cabeça com cérebro e sua política, ativa, tinha «razão de estado». O amor e a força eram as duas faces de sua Coroa. Os limites reais para a construção de um poder ausente, as necessidades e interesses econômicos da monarquia definiram o equilíbrio instável das relações de poder entre a negociação e a coerção.

Cada novo agente, ou força social, que se inseria nos espaços ultramarinos aumentava a complexidade do jogo político, porque a associação entre os grupos de interesse e de poder, nos Reinos e nas conquistas, era natural. A lógica da política régia era o divide et impera e só na aparência era contraditória, porque precisava negociar e subordinar forças e interesses divergentes. A dominação sobre as populações não cristãs, longe de ser um problema do âmbito doméstico, foi o elemento central para a construção de uma nova ideia de soberania e para a reconfiguração das relações de poder na modernidade.

\section{BiBLIOGRAFIA}

Albuquerque, Luís de (dir.), Angola no século XVI, Lisboa, Alfa, 1989.

Alencastro, Luiz Felipe de, $O$ trato dos viventes: formação do Brasil no Atlântico Sul, São Paulo, Companhia das Letras, 2000.

ABNRJ Anais da Biblioteca Nacional do Rio de Janeiro, vol. XXVII (Rio de Janeiro, 1906) e vol. LXII, (Rio de Janeiro, 1942). 
Bouza, Fernando, "De un fin de siglo a otro. Unión de Coronas Ibéricas entre don Manuel y Felipe II", El Tratado de Tordesillas y su época, vol. 3, Valladolid, Junta de Castilla y León/Sociedad V Centenario del Tratado de Tordesillas, 1995: 1453-1463.

Bowser, Frederick P., El esclavo africano en el Perú colonial (1524-1650), México, Siglo XXI, 1977.

Brásio, António (col. e anot.), Monumenta Missionária Africana, vols. III e IV, Lisboa, Agência Geral do Ultramar, 1953 e 1954.

Cortés Rojas, Ignacia, Bartolomé de Las Casas y el Parecer de Yucay, Lima, Editorial Universitaria, 2011.

Cuena Boy, Francisco, "Yaconazgo y derecho romano: ¿una conjunción extravagante", Revista de estudios histórico-jurídicos, 28 (Valparaíso, 2006): 401-424.

Documentos para a história do açúcar, vol. 1, Rio de Janeiro, Serviço especial de documentação histórica, 1954.

García-Gallo, Alfonso, Estudios de Historia del Derecho Indiano, Madrid, Instituto Nacional de Estudos Jurídicos, 1972.

Godinho, Vitorino Magalhães, Os descobrimentos e a economia mundial, vol. 4, Lisboa, Editorial Presença, 1983.

Hansen, João Adolfo, A sátira e o engenho: Gregório de Matos e a Bahia do século XVII, Campinas, Ateliê editorial, Editora da Unicamp, 2004.

Heintze, Beatrix, Angola nos séculos XVI e XVII: Estudos sobre fontes, métodos e história, Luanda, Kilombelombe, 2007.

Hemming, John, La conquista de los incas, México D.F., FCE, 2000.

Hespanha, António M., "O Governo dos Áustrias e a 'Modernização' da Constituição Política Portuguesa”, Penélope, 2 (Lisboa, 1989): 49-73.

Julien, Catherine, "Francisco de Toledo and his campaign against the Incas", Colonial Latin American Review, 16/2 (Alburquerque, USA, dezembro 2007): 243-272.

Leite, Serafim (ed.), Cartas dos primeiros jesuitas no Brasil, 3 vols., São Paulo, Comissão do IV Centenário da Cidade de São Paulo, 1954.

Merluzzi, Manfredi, "Mediación política, redes clientelares y pacificación del reino en el Perú del siglo XVI. Observaciones a partir de los papeles 'Pizarro - La Gasca", Revista de Indias, LXVI / 236 (Madrid, 2006): 87-106.

Monteiro, John, Negros da terra: indios e bandeirantes nas origens de São Paulo, São Paulo, Companhia das Letras, 1994.

Monteiro, John, "Labor Systems", J. Coatsworth, R. Cortes-Conde, V. Bulmer-Thomas (orgs.), Cambridge Economic History of Latin America, vol. 1, Cambridge, Cambridge University Press, 2006: 185-234. 
Mumford, Jeremy R., "Francisco de Toledo, admirador y émulo de la 'tiranía' inca", Historica, XXXV/2 (Lima, 2011): 45-57.

Murra, John V., La organización económica del Estado Inca, México, Siglo XXI, 1978 .

Peña, Juan de la, De bello contra insulanos, vol. 2, Madrid, CSIC, 1982.

Poma de Ayala, Felipe Guaman, Nueva corónica y buen gobierno, vol. II, México D.F., FCE, 2005.

Poole, Stafford, Juan de Ovando: governing the Spanish Empire in the Reign of Philip II, Norman, University of Oklahoma Press, 2004.

Puntoni, Pedro, "O governo-geral e o Estado do Brasil: poderes intermédios e administração (1549-1720)", Stuart Schwartz e Erik Myrup (orgs.), O Brasil no império maritimo português, Bauru, SP, Edusc, 2009: 39-73.

Schwartz, Stuart B., Burocracia e sociedade no Brasil colonial: o Tribunal Superior da Bahia e seus desembargadores, 1609-1751, São Paulo, Companhia das Letras, 2011.

Silva, Alberto da Costa e, A manilha e o libambo: a África e a escravidão, de 1500 a 1700, Rio de Janeiro, Nova Fronteira, 2002.

Stern, Steve J., Los pueblos indígenas del Perú y el desafio de la conquista española. Huamanaga hasta 1640, Madrid, Alianza Editorial, 1982.

Spalding, Karen, Huaracochirí: An Andean Society Under Inca and Spanish Rule, Stanford, Stanford University Press, 1984.

Thomas, Georg, Política indigenista dos portugueses no Brasil 1500-1640, São Paulo, Edições Loyola, 1981.

Vainfas, Ronaldo, A heresia dos índios: catolicismo e rebeldia no Brasil colonial, São Paulo, Companhia das Letras, 1995.

Varnhagen, Francisco Adolfo de, História Geral do Brasil, vol. 1, São Paulo, Melhoramentos, 1978.

Fecha de recepción: 11 de junio de 2014.

Fecha de envío de las modificaciones: 22 de octubre de 2014.

Fecha de aceptación: 22 de octubre de 2014. 


\section{Guerra, dominio y soberanía: experiencias coloniales e imperio en el Atlántico Sur, década de 1570}

A través del análisis de los documentos y de la historiografia, el artículo identifica la constitución de un campo unificado de experiencias de colonización en el Atlántico Sur, durante la década de 1570. La caracterización de la autoridad regia sobre los espacios coloniales pasaba, de una parte, por la institución de un aparato político-administrativo, y de otra, por la intervención en las relaciones de dominio señorial establecidos sobre los indígenas y africanos. Este último fue el punto de compromiso y disensión, que definía el equilibrio inestable entre los poderes coloniales y las autoridades europeas mediante un sistema de explotación compuesto, caracterizado por la complementariedad entre diferentes estatutos y formas de dominación.

Palabras Clave: guerra; dominio; soberania; imperio; Atlántico Sur.

\section{War, dominion and sovereignty: South Atlantic colonial experiences and empire in the $1570 \mathrm{~s}$}

By analysing documents and historiography, the article identifies the constitution of a unified field of colonization experiences in the South Atlantic during the 1570s. Royal authority over colonial spaces was characterized, on the one hand, by the institution of politicaladministrative apparatus, and on the other, by intervention in the manorial relations to which native Africans and Americans were subjected. The latter created a point of compromise and dissension that marked the instability between colonial powers and European authorities, using a system of composite exploitation, characterized by complementarity between different statutes and forms of domination.

KEY WORDS: war; dominion; sovereignty; empire; South Atlantic. 